DRUŠ. ISTRAŽ ZAGREB GOD. 20 (2011),

STR. 271-290

upravljanju kulturnim dobrima koja nisu konačna, dapače, oni su osnova za daljnju kreativnost $i$ istraživanje vezano za upravljanje kulturnim dobrima! Autorica ističe i zaključuje kako je pojam kulturne baštine vrlo kompleksan, jer uključuje više razina koje zahtijevaju vrlo suptilan pristup, jer nije isto upravljati materijalnim i nematerijalnim dobrima, kao što nije isto upravljati kulturnim dobrima te onima koja uključuju i elemente prirodne baštine. Jednako tako i upravljanje kulturnim dobrima traži jedinstven pristup svakom pojedinom kulturnom dobru te prilagodbu specifičnim uvjetima, koji često određuju način upravljanja njime.

Mislim kako će knjiga "Kultura u izlogu" svojim interdisciplinarnim i inovativnim pristupom poslužiti kao primjer svim istraživačima, sadašnjima i budućima, kvalitetne dopune oskudne literature o upravljanju kulturnim dobrima i institucijama, ali i kao podloga i poticaj za nova istraživanja ne samo na području kulture nego i šire.

Rebeka Mesarić Žabčić

doi:10.5559/di.20.1.17

\section{Jonah Lehrer THE DECISIVE MOMENT. HOW THE BRAIN MAKES UP ITS MIND}

Canongate Books, Edinburgh, 2010., 294 str.

Knjiga mladoga američkog autora, psihologa Jonaha Lehrera, objavljena je pod dva naslova: početno, u SAD-u, pod naslovom How We Decide (Kako odlučujemo), a potom u identičnom britanskom džepnom izdanju pod naslovom Odlučan trenutak. Kako mozak donosi odluke. Oba naslova podjednako dobro opisuju sadržaj knjige. Prije objavljivanja ove knjige Lehrer je radio u laboratoriju nobelovca Erica Kandela, objavio je knjigu Proust kao neuroznanstvenik, a redovito piše za New Yorker, Washington Post i Boston Globe te uređuje blog Scientific Americana "Mind Matters" i piše vlastiti, vrlo cijenjeni blog The Frontal Cortex. Knjigu Kako odlučujemo (odnosno Odlučan trenutak) s pravom su pohvalili Oliver Sacks, Tom Vanderbilt, Antonio Damasio i Dan Ariely. Knjiga Odlučan trenutak nastavlja vrlo bogatu recentnu izdavačku djelatnost američkih nakladnika, ali i stil knjiga poput Arielyjevih Predvidljivo iracionalni i Prednosti iracionalnosti, Gigerenzerovih - Snage intuicije i Racionalnosti za smrtnike, Harfodovih - Ekonomist na tajnom zadatku i Logika života, Levitt-Dubnerove Freakonomije (i novije Superfrikonomije), Gladwellovih - Blink i Tipping Point, Thaler-Sunsteinove knjige Poticaj, Gilbertove knjige Mit o sreći, knjige braće Brafman Sway, Mlodinowljeve Korak pijanice, Talebova Crnog labuda ili starijih knjiga poput Damasiove Descartesove greške. (Naši izdavači u toj bujici zanimljivih znanstveno-popularnih knjiga drže dobar korak.)

Navedene knjige ocrtavaju razmjerno novo i nejasno ograničeno znanstveno područje pod imenom "bihevioralna ekonomija" ili psihologija odlučivanja, jednostavno: istraživanje standardnih (tipičnih) pogrešaka koje ljudi rade $u$ statističkom razmišljanju, ponašanju i posebno - pri odlučivanju. Od sedamdesetih godina, kada su nobelovci (2002.) Daniel Kahneman i Vernon Smith te Reinhardt Selten (1994.), ali posebno Kahneman i njegovi suradnici Tversky, Gilowich, Griffin, Slovic i dr., počeli eksperimentalno upozoravati na sistematske "poremećaje" naše racionalnosti, nije se iznjedrila sistematska teorija našega ponašanja i odlučivanja. Pri odlučivanju radimo tipične, sistemske pogreške, ali zašto do njih dolazi, kakva bi bila evolucijska svrha naše iracionalnosti, je li na- 
DRUŠ. ISTRAŽ. ZAGREB

GOD. 20 (2011)

STR. 271-290

ša sistemska "iracionalnost" evolucijski ili "ekološki" ipak adaptivna, o tome još nemamo definitivne odgovore.

Za razliku od spomenutih knjiga koje stavljaju različite naglaske na eksperimentalni karakter područja istraživanja racionalnosti, ili tzv. istraživanja pristranosti i heuristika, Lehrerova knjiga, odnosno dvadesetak priča u njoj, ističe važnost jednog još novijeg smjera istraživanja $u$ bihevioralnoj ekonomiji - tzv. neuroekonomije. Neuroekonomija je poddisciplina koja istražuje što se događa u našem mozgu prilikom donošenja odluka, odnosno koji sve biološki čimbenici utječu na to da $\mathrm{u}$ istim situacijama donosimo ispravne ili pogrešne odluke.

Dosad vladajuća teorija koja je trebala objasniti te sistemske pogreške zvala se "teorija dvostrukoga procesuiranja". Budući da niz dojmova koje dobivamo iz vanjskoga svijeta ne možemo isključivo svjesno prerađivati, jedan dio našega ponašanja procesuira se (gotovo) automatski - emocionalno. Naš se um, dakle, koristi i emocionalnim i kognitivno-racionalnim procesuiranjem. Pogreške nastaju kada obradbu dojmova "preuzme" krivi način procesuiranja, a takve su situacije tipične $\mathrm{u} u$ vjetima brzog odlučivanja, jer tada rabimo emocionalno-"intuitivni" način procesuiranja umjesto kognitivnog, odnosno kada racionalno pokušavamo donijeti isuviše složenu odluku za koju bi bilo dovoljno isključivo emocionalno procesuiranje. Ta je teorija prilično nespecifična u predviđanju pogrešaka, a rafiniranje te teorije moglo bi se pojaviti umnažanjem podataka o stvarnom moždanom procesuiranju $\mathrm{u}$ određenim situacijama. (Naravno, slike moždane aktivnosti za sada možemo dobiti samo simulacijama stvarnih situacija u uređajima za magnetsku rezonanciju ili PET-skenovima.)
Lehrer započinje filozofskim metaforama kojima su se služili Platon, Descartes i drugi o razumu kao jahaču koji upravlja divljim konjima (emocijama) ili pak o apolonskoj logici protiv dionizijske emocionalnosti. Za njih Lehrer kaže: "Te dihotomije nisu samo pogrešne, one su destruktivne. Katkada nam treba razum kako bismo pažljivo analizirali mogućnosti. A katkada moramo slušati svoje emocije. Tajna leži u tome da spoznamo kada upotrijebiti te razne stilove mišljenja. Mi nismo navikli da svoje izbore razumijevamo u terminima konkurirajućih moždanih regija ili različitim stopama paljenja neurona. Pa ipak, taj novi način spoznavanja samih sebe - pokušaj da ljudsko ponašanje shvatimo iznutra - otkrit će nam mnoge iznenađujuće stvari ... Ali mozak ne postoji u vakuumu; sve se odluke donose u kontekstu stvarnoga svijeta. Herbert Simon, nobelovac psiholog, usporedio je ljudski um sa škarama. Jedna je oštrica mozak, rekao je, dok je druga specifična okolina u kojoj mozak djeluje. Ako želimo razumjeti funkciju škara, moramo promatrati obje oštrice istodobno (str. 5-6) ... Klasična teorija temelji se (stoga) na ključnoj pogrešci. Predugo smo prezirali emocionalni mozak i krivili osjećaje za svoje pogreške. Istina je mnogo zanimljivija. Kada pogledamo mozak, otkrit ćemo da konji i jahač ovise jedni o drugima. Kada ne bi bilo emocija, razum uopće ne bi postojao" (str. 20).

Prvi "prodor" $u$ istraživanje emocionalnoga mozga bilo je Damasiovo "otkriće" da nam za donošenje odluka trebaju emocije, jer bismo bez njih bili uhvaćeni u zamku beskonačnoga razumskog ponderiranja raznih mogućnosti. Premda je osobama s oštećenjem orbitofrontalnog režnja netaknuta sposobnost logičkog rezoniranja, one ne mogu donijeti odluku jer im je uništen emocionalni dio odgovoran za "prekidanje pretraživanja mogućnosti". (I na tome planu treba srušiti klasičnu predrasudu - o tome da je evolucijski najmlađi dio mozga, moždana kora, ono što nas uistinu čini racionalnima.) $U$ tom dijelu mozga stvaraju se veze s "primitivnim" di- 
DRUŠ. ISTRAŽ ZAGREB GOD. 20 (2011)

STR. 271-290

jelom mozga - područjima poput moždane stapke i amigdale sa strujom svjesne misli. "Kada se poremeti ta povezanost živaca, gubimo dostupnost bogatstvu mišljenja na koje se obično oslanjamo. Odjednom više ne znamo što mislimo ... a krajnji je rezultat da ne možemo donijeti pristojnu odluku (24-5). Prema istraživanjima emocija, velik dio naših "misaonih procesa" vode emocije. Za Josepha le Douxa, istraživača emocija, svaki je osjećaj "sažetak niza podataka", tjelesna reakcija na sve one informacije koje nam nisu izravno dostupne. Mozak skuplja informacije mnogo prije negoli što smo svjesni da to čini, pa se "emocionalna reakcija" svijesti čini nasumičnom, premda nije tako.

U slučajevima kada se dogodi što neočekivano, u mozgu se naglo počinju proizvoditi molekule neurotransmitera dopamina u tzv. nucleusu accumbensu (NAcc). (On inače služi za stvaranje osjećaja ugode i za regulaciju svih naših emocija.) Praćenje putanje neurotransmitera omogućuje nam, osim dobrih osjećaja, i analizu funkcioniranja emocija. Primjerice, pokazalo se da dopamin pokreće neurone prije same "nagrade", mehanizam nagrađivanja pokreće se prije same nagrade. "Neurone predviđanja" više zanima predviđanje nagrada od nagrade same. Ali jednom kada naučimo taj sustav, "dopaminski neuroni postaju vrlo osjetljivi na varijacije količine dopamina (a to znači da one služe kao) signali za predviđanje pogreške." Drugim riječima, dopaminski sustav izrađuje sustav očekivanja, a mozak uspoređuje "predviđanja" s onim što se stvarno zbiva. "Kada sve ide po planu, dopaminski neuroni izlučuju malu količinu ugode. Ali kada se očekivanja ne potvrde dopaminske stanice počinju štrajkati. One odjednom počinju slati signale koji obznanjuju svoju pogrešku i prestaju lučiti dopamin. Mozak je pak dizajniran tako da pojača šok tih pogrešnih predviđanja. Milisekundu kasnije, aktivnost moždanih stanica pretvorila se u snažnu emociju" (str. 42-3). Vrlo velik broj "dopaminskih stanica" nalazi se u stražnjem cingulatnom režnju (ACC), i taj je dio mozga odgovoran za otkrivanje pogrešaka. On je odgovoran za stvaranje osjeta kojim će osoba odmah primijetiti neočekivani događaj. Istodobno, on "pamti" razinu dopamina, odnosno ugađa tu razinu očekivanja, tako da se "kratkotrajni osjećaj pretvara u dugoročnu lekciju (a to je) osnovni aspekt odlučivanja" (str. 44). Poremećaji toga sustava, koji mogu biti i genetske prirode, dovode do vrlo važnih posljedica, primjerice bolesti koje onemogućuju donošenje pravilnih reakcija na promjenljive razine dopamina. Istodobno, mi i učimo o svojim pogreškama, i na taj način (nesvjesno) ugađamo biokemijski sustav odlučivanja, odnosno razine dopamina.

Lehrer pruža niz primjera i eksperimentalnih nalaza koji bi isključivo razmatranjem svijesti bili neobjašnjivi. Primjerice, kako to da su u eksperimentima Carol Dweck sa Stanforda bolje rezultate postizali učenici koje su hvalili zbog njihova truda negoli zbog njihovih rezultata. Odgovor: zbog toga što su učenici pohvaljeni zbog truda bili skloniji učiti na vlastitim pogreškama (tj. ugađati dopaminski sustav), a to je pak omogućilo da u sljedećim testovima postižu bolje rezultate od onih koji su svoje rezultate smatrali "urođenim" stanjem ili proizvodom vlastite inteligencije.

Ali istraživanje dopamina isto tako pokazuje kako je moguće stvoriti ovisnosti (nasumični pogoci donose više užitka) ili zašto smo skloniji raditi "pogreške niza", primjerice kada uočavamo seriju pogodaka (u košarci) ili kada uočavamo obrasce "rasta" ili pada dionica na burzi, premda je zapravo riječ o statistički posve nasumičnim događajima (mozak proizvodi i fiktivne obrasce). Emocije, dakle, ne čine cijelu priču. "Najbolji donositelji odluka znaju 
DRUŠ. ISTRAŽ. ZAGREB

GOD. 20 (2011)

RECENZIJE I PRIKAZI

BR. 1 (1 111 ),

STR. $271-290$

koje situacije zahtijevaju manje intuitivne odgovore ... Nažalost, isti živčani krugovi koji su dobri u praćenju nagrada ... mogu potpuno pogriješiti u posve nepredvidljivim situacijama (time što stvaraju obrazac)" (str. 71).

Kao što postoji niz situacija u kojima "nismo razmišljali" već postupali intuitivno (i pogriješili), tako postoje i suprotne situacije, kada nas je upravo razmišljanje dovelo do pogreške. Takve su situacije tipične za genije neke fizičke vještine, primjerice operne pjevačice, glumce ili sportaše, za situacije u kojima ljudi, umjesto da se prepuste "navici", tijekom izvođenja radnje počinju razmišljati o vlastitoj tehnici. "Za izvođača takvo razmišljanje može biti kobno" (str. 133). Dok je za slabog igrača dobro da razmišljanjem popravlja svoje pogreške, za dobrog je takva strategija porazna. Isto tako, za donošenje odluka manji izbor opcija često je bolji od većega. U takvim su situacijama emocije vrlo dobri vodiči. Kako bi objasnio zašto je to tako, Lehrer prikazuje istraživanja placebo efekta, koji nam govori o tome što se zbiva kada nas racionalni dio mozga (prefrontalni režanj) priprema za odluke: premda nam katkada zbog povišene razine očekivanja boli može biti "bolje" jer osjećamo manju bol, taj mehanizam dovodi do toga da zanemarujemo emocionalne reakcije i tada se svijest upleće $u$ dobar sustav odlučivanja.

Za svaku neurološku spoznaju Lehrer pruža niz primjera iz života. To čini snagu njegove knjige, ali i mogući nedostatak - za sve one koji traže jezgrovit prikaz naših spoznaja o neurologiji odlučivanja. (Pamtimo li bolje na primjerima? Ili "sistemskim prikazom"? - to vjerojatno ovisi o našem karakteru.) Ali za istraživače bihevioralne ekonomije možda je najpoučniji dio Lehrerove knjige onaj kad je popriličan niz dobro istraženih "pristranosti" $i$ heuristika (primjerice, povećanu sklonost rizicima kada već gubimo, iluziju obrasca, zanemarivanje regresije prema srednjoj vrijednosti, zanemarivanje prvobitnih vjerojatnosti i dr.) protumačio uz pomoć neurologije (točnije - biokemije) mozga, a takav prikaz do sada nije bio tipičan. Tople preporuke za čitanje (i prevođenje).

Darko Polšek

doi:10.5559/di.20.1.18

\section{VJERNICE I GRADANKE}

Zilka Spahić-Šiljak, Rebeka Jadranka Anić (ur.)

TPO fondacija i CIPS-Univerziteta u Sarajevu, Sarajevo, 2009., 242 str.

Knjiga I vjernice i građanke nastala je u sklopu projekta Modifikacija društvenih i kulturnih obrazaca ponašanja muškaraca i žena u Bosni i Hercegovini, čiji je cilj promocija ženskih ljudskih prava, posebice članka 5. Konvencije o uklanjanju svih oblika diskriminacije žena i Rezolucije 1325 o ženama, miru i sigurnosti. Imajući na umu važnost religije i njezin utjecaj na definiranje modela rodnih odnosa, knjiga donosi pregled učenja katoličke, pravoslavne $\mathrm{i}$ islamske vjerske zajednice o ljudskim pravima žene, nastojeći otvoriti široko područje dijaloga i suradnje civilnoga i vjerskoga sektora na području promocije ženskih ljudskih prava. Knjiga obuhvaća četiri rada. Prvi donosi pregled pravnih instrumenata zaštite ženskih ljudskih prava, dok ostala tri nude pogled na ljudska prava žene iz perspektive triju navedenih vjerskih zajednica. Radovi se dijele $u$ pet tematskih cjelina, $u$ kojima se razmatraju: dostojanstvo osobe, modeli rodnih odnosa, rodni odnosi u obitelji, rodna perspektiva u društveno-političkom životu i mirotvorstvo. 